\title{
Nitric oxide unravels the enigmatic function of the paranasal sinuses: a review of literature
}

\author{
Remon Bazak* (D), Samy Elwany, Amir Mina and Mostafa Donia
}

\begin{abstract}
Background: The physiological functions of the paranasal sinuses are as yet unclear, and it is often assumed that these empty air-filled spaces have no vital function in our body. Recently, nitric oxide has been reported to be synthetized in high concentration by the paranasal sinuses which seems to be the main function of these air-filled empty spaces.

Body of abstract: The functional role of the paranasal sinuses is still ambiguous despite the several hypotheses that have been put forward to justify their existence. Although it has been recently demonstrated that the paranasal sinuses produce large amounts of nitric oxide (NO), otolaryngologists overwhelmed by attempting to unravel the enigmatic etiology underlying chronic rhinosinusitis have interpreted the high NO output in this context. Nevertheless, NO prime function is vasodilation and has long been recognized to be produced by the endothelial cells. In this review, evidence in the literature is piled and pieces of the puzzle are put together to show that NO synthesized in the paranasal sinuses functions as an airborne messenger that induces pulmonary vasodilation and thereby decreases the workload on the heart. Recognition that the paranasal sinuses are in fact an organ with known function is likely to foster further research and has an impact on our current surgical philosophy.

Conclusion: The paranasal sinuses seem to play a vital physiological role in our body rather than being evolutionary remnants as initially thought. They are likely responsible for regulating the pulmonary blood pressure thereby preventing pulmonary hypertension.
\end{abstract}

Keywords: Nitric oxide, Pulmonary hypertension, Paranasal sinuses, Function, Heart

\section{Background}

Detailed knowledge of the physiological functions of each organ in our body is well known to physicians treating that organ under their domain. Otolaryngologists have been increasingly overwhelmed with management diseases afflicting the paranasal sinuses, and exploration of novel endoscopic approaches to target pathologies within and beyond the confines of these sinuses. Nevertheless, the physiological function of these sinuses is as yet unclear.

\footnotetext{
*Correspondence: dr_remon77@yahoo.com

Department of Otorhinolaryngology, Faculty of Medicine, University of Alexandria, Alexandria, Egypt
}

Several hypotheses have been put forward to explain the existence of the paranasal sinuses; however, none has gained widespread acceptance, and it has been assumed that these empty air-filled spaces do not serve a vital function. The recent discovery of production of nitric oxide (NO) by the mucosal lining of the paranasal sinuses is likely to unravel the obscure function of these empty air-filled spaces.

\section{Main text}

It has been hypothesized that the main purpose of the paranasal sinuses is to lighten the weight of the skull to maintain the equipoise posture of the head on the spine, thereby preventing fatigue of the posterior cervical

\section{Springer Open}

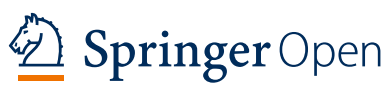

(c) The Author(s). 2020 Open Access This article is licensed under a Creative Commons Attribution 4.0 International License, which permits use, sharing, adaptation, distribution and reproduction in any medium or format, as long as you give appropriate credit to the original author(s) and the source, provide a link to the Creative Commons licence, and indicate if changes were made. The images or other third party material in this article are included in the article's Creative Commons licence, unless indicated otherwise in a credit line to the material. If material is not included in the article's Creative Commons licence and your intended use is not permitted by statutory regulation or exceeds the permitted use, you will need to obtain permission directly from the copyright holder. To view a copy of this licence, visit http://creativecommons.org/licenses/by/4.0/. 
musculature [1-3]. However, it has been calculated that if these spaces are filled with bone, this would increase the weight of the head by only $1-2 \%[1,4,5]$. Biggs and Blanton [4] have demonstrated that at least 6 ounces of weight have to be added to the anterior head in order to elicit electromyographic changes in the posterior cervical musculature. Six ounces of weight is $2-3$ times greater than the weight of bone required to fill the paranasal sinuses which makes this hypothesis unlikely.

It has also been hypothesized that the paranasal sinuses' main function is to impart resonance to our voices $[1,6]$. However, it is interesting to know that the lion with its strong resonant roar that can be heard over 5 miles has small paranasal sinuses while the giraffe with its feeble voice has large paranasal sinuses [1]. In fact, the small ostial size of the paranasal sinuses renders them poor resonators of voice and stands against this function.

The sinuses have been perceived as thermal insulators that function to insulate the central nervous system from the cold air currents passing through the nasal cavity [7]. Nevertheless, the skulls of Japanese macaques living in cold areas at high altitudes have paranasal sinuses which are smaller than those of the same species but living in warmer areas [8]. Again, in humans, the frontal sinuses of Eskimos have been reported to be hypoplastic compared to the hyperpneumatized frontal sinuses in Negros $[9,10]$. Therefore, thermal insulation of the brain does not seem to be the main function of the paranasal sinuses.

The paranasal sinuses are often assumed to be the major source of mucous in our nasal cavities. However, it has been estimated that there are around 50-100 submucous glands in our paranasal sinuses which is a small number compared to 100,000 submucous glands in our nasal cavities [1]. So, under physiological conditions, the paranasal sinuses are not the major source of mucous. In chronic pathological conditions, hyperplasia and hyperactivity of the submucous gland take place in the paranasal sinuses and might result in excessive mucous production and post-nasal discharge $[11,12]$. Nonetheless, it is implausible that the main function of these airfilled spaces is to produce mucous when infected.

Air exchange through the paranasal sinuses takes place during respiration, and therefore, it is logical to assume that these large air-filled spaces act as thermoregulators and air humidifiers. However, it has been estimated that only $1 / 1000$ of the air in the sinuses is exchanged during one respiratory cycle [13] which questions their thermoregulatory function.

More interestingly, the sinuses have been perceived as a floatation device that aids to keep the head floating while swimming and keep the nostrils out of the water [14]. This is well demonstrated in crocodile's gesture, where the entire body except the head is submerged under water. This hypothesis is based on the aquatic ape theory, which assumes that man has once moved from water to land and these sinuses are remnants of his earlier aquatic life [15]. Nevertheless, the skull of dolphins and whales which still need to surface and breathe air does not have air-filled bony spaces $[16,17]$.

Therefore, it is not surprising that Negus [18] has once considered the paranasal sinuses evolutionary remnants of useless air spaces. He has stated "There does not appear to be any functional reason for the appearances of the paranasal sinuses, and the irregularity of their distribution, often with complete absence, suggests that they are only unwanted residual spaces."

Despite this ambiguity, we cannot deny the fact that almost all living creatures possessing a lung do have paranasal sinuses, all the way from dinosaurs, crocodiles, mammals, and birds. Even dolphins and whales which have lost their limbs as an adaptation to aquatic life did not lose their paranasal sinuses in their entirety. Instead, the paranasal sinuses came out of the confines of the skull and became paranasal air sacs [16]. Indeed, having a non-porous skull is an adaption to maintain the integrity of their skulls during deep sea diving thereby avoiding barotrauma. Therefore, it seems that the mucous membrane lining of the paranasal sinuses is the functional element rather than the bony cavity of the paranasal sinuses.

Until recently, NO has been considered just an air pollutant as a byproduct of fuel combustion. In 1987, Ignarro et al. [19] and Palmer et al. [20] independently demonstrated that the previously recognized endothelial derived relaxing factor (EDRF) which is released from the vascular walls is essentially NO. This has shed light that NO might have a role in our biological systems and enthused further research that have led to a plethora of discoveries including the development of phosphodiesterase- 5 inhibitors used in management of erectile dysfunction. In fact, Ignarro's work was later acknowledged and earned him the Nobel Prize in 1998 [21].

In 1991, Gustafsson et al. [22] demonstrated that NO is present in the exhaled air of rabbits, guinea pigs, and humans which has inspired further research exploring the presence $\mathrm{NO}$ in the respiratory tract. Three years later, Lundberg et al. [23] demonstrated that the concentration of NO in exhaled air from the nose in normal subjects is nearly 10 -fold compared to that from patients with permanent tracheostomies. This finding pointed out that the primary site of NO production is somewhere in the sinonasal tract.

In 2003, Maniscalco et al. [24] reported that in healthy subjects, nasal NO levels increase greatly during humming compared to silent exhalation. This humminginduced NO peak has been found to decline with 
consecutive repeated humming maneuvers but recovers completely after a silent period of $3 \mathrm{~min}$. Topical application of NO synthase inhibitor reduced nasal NO by > $50 \%$ but had no effect on humming-induced NO peak. It has been proposed that humming-induced vibrations in the sinus wall facilitate air exchange across the sinus ostia which expels the retained NO. This was later confirmed by demonstrating that humming-induced $\mathrm{NO}$ peak is abolished in patients with endoscopic evidence of ostial obstruction [25].

Vaidyanathan et al. [26] in 2010 have demonstrated that patients with chronic rhinosinusitis with nasal polyps lack the humming-induced $\mathrm{NO}$ and that a course of systemic steroids for 2 weeks resulted in increase in humming-induced NO presumably due to reaeration of sinus ostia. In line with the above, several studies have suggested the role of $\mathrm{NO}$ as a non-invasive marker of sinus ostial patency [26-28].

$\mathrm{NO}$ is synthesized from L-arginine by nitric oxide synthase (NOS) which has two isoforms: a constitutive form and an inducible form [29, 30]. The constitutive form produces small amounts of $\mathrm{NO}$ at a basal level and is expressed by the epithelial cells of the entire respiratory tract [31-33]. On the other hand, the inducible form is present in inflammatory cells and produces high levels of NO up to 1000 -fold that is produced by the constitutive form [34]. It has been recently demonstrated that an isoform of inducible NOS is constitutively expressed by the epithelial cells lining the paranasal sinuses [35]. In contrast, only weak NO synthase activity was found in the epithelium of the nasal cavity. Therefore, despite the morphologic similarity of the nasal and paranasal sinus mucosa, functionally, they seem to be different.

Nitric oxide concentrations in the lower airways of tracheostomized and intubated patients are as low as 2-4 ppb [22], while a concentration in the range of 22,300$29,000 \mathrm{ppb}$ has been detected in the paranasal sinuses $[33,35]$. This clearly indicates that the primary source of respiratory $\mathrm{NO}$ is the paranasal sinuses. Upon recognition of NO production by the paranasal sinuses, the scientific community engrossed in unraveling the etiology of chronic rhinosinusitis has erroneously interpreted this finding in the context of etiopathogenesis of chronic sinonasal disorders [27, 36-39]. Interestingly, NO levels in the maxillary sinus has been shown to undergo fluctuations during respiration [40] which suggests that NO is released during respiration. Holden et al. [41] found that NO concentration within the nasal cavity is approximately 3-fold greater during inhalation compared with exhalation, and NO concentration increases nearly 6fold as air moves from the nasal sill to the posterior oropharynx. Collectively, these findings suggest that high output of NO produced by the paranasal sinuses travels during inspiration to the lower respiratory tract.
In 1991, Frostel et al. [42] demonstrated in an animal model of pulmonary hypertension that inhaled NO acts as a vasodilator which decreases pulmonary vascular pressure. Subsequent research consolidated this finding [43-47] and has led to FDA approval of inhaled NO as a treatment modality for neonatal pulmonary hypertension in 1999 [48, 49]. It is well documented in the literature that chronic oral breathing secondary to adeno-tonsillar hypertrophy induces pulmonary hypertension, right ventricular strain, and eventually right heart failure [50-55]. This entity has been termed "hypoxic corpulmonale" and has been erroneously attributed to alveolar hypoventilation [56]. Neither the amount of inhaled oxygen nor the alveolar ventilation should vary if air is inhaled from the mouth instead of the nose. However, breathing through the mouth deprives the lungs from the endogenously produced NO and is likely to result in the observed increase in the pulmonary vascular pressure and right ventricular strain.

\section{Conclusion}

Based on the above, it seems that the paranasal sinuses are in fact an organ rather than evolutionary remnants. The prime function of this organ is to produce NO which travels downstream with the inspired air to decrease pulmonary vascular resistance and thereby decrease the workload on the heart. Further research work on nitric oxide in this context is likely to reveal interesting data and influence our current surgical philosophy of enlarging the ostia of the paranasal sinuses to improve their drainage.

\section{Abbreviations}

EDRF: Endothelial derived relaxing factor; NO: Nitric oxide; NOS: Nitric oxide synthase

\section{Acknowledgements \\ Not applicable}

\section{Authors' contributions}

$\mathrm{RB}$ proposed the idea, collected and interpreted the data, and contributed in writing the review article. All other authors had a major contribution in writing the manuscript. SE and RB critically analyzed the literature related to the proposed hypothesis of the functions of the paranasal sinuses and subsequently wrote that part of the manuscript. AM, MD, and RB interpreted the data that pertains to nitric oxide in the literature in view of the proposed function of the paranasal sinuses and have written the remaining part of the manuscript. After the review article was written, SE has made some minor modifications, and all authors approved the final manuscript.

\section{Funding}

None

Availability of data and materials Not applicable

Ethics approval and consent to participate Not applicable

Consent for publication Not applicable 


\section{Competing interests}

The authors declare that they have no competing interests.

\section{Received: 28 March 2020 Accepted: 20 May 2020 Published online: 12 August 2020}

\section{References}

1. Keir J (2009) Why do we have paranasal sinuses? J Laryngol Otol 123:4-8

2. Anson BJ (1966) Morris human anatomy, 12th edn. McGraw-Hill, New York

3. Wright J (1914) History of laryngology and rhinology, 2nd edn. Lea and Pebiger, Philadelphia

4. Biggs NL, Blanton PL (1970) The role of paranasal sinuses as weight reducers of the head determined by electromyography of postural neck muscles. J Biomech 3:255-262

5. Braune W, Clasen FE (1877) Die Nebenhohlen der Menschlichen Nase in ihre Bedeutung fur den Mechanismus des Riechens. Zeit Ent 2:S.1

6. Howell HP (1917) Voice production from the stand point of the laryngologist. Ann Otol Rhin Laryngol 26:643-655

7. Proetz AW (1953) Applied physiology of the nose, 2nd edn. Annales Publishing, Saint Louis

8. Rae TC, Hill RA, Hamada Y, Koppe T (2003) Clinal variation of maxillary sinus volume in Japanese macaques (Macaca fuscata). Am J Primatol 59:153-158

9. Koertvelyessy $T$ (1972) Relationships between the frontal sinus and climatic conditions: a skeletal approach to cold adaptation. Am J Phys Anthropol 37: $161-172$

10. Wolfowitz BL (1974) Pneumatization of the skull of the Southern African Negro. PhD thesis, University of Witwatersrand.

11. Tos M, Mogensen C (1984) Mucus production in chronic maxillary sinusitis. A quantitative histopathological study. Acta Otolaryngol 97:151-159

12. Petruson B (1994) Secretion from gland and goblet cells in infected sinuses. Acta Otolaryngol Suppl 515:33-36 discussion 36-37

13. Passàli D, Passàli GC, Passàli FM, Bellussi L (2004) Physiology of the paranasal sinuses. In: Levine H, Clemente MP (eds) Sinus surgery: endoscopic and microscopic approaches, 1st edn. Thieme, New York, pp 57-62

14. Rhys Evans PH (1992) The paranasal sinuses and other enigmas: an aquatic evolutionary theory. J Laryngol Otol 106:214-225

15. Hardy A (1960) Was man more aquatic in the past? New Scientist 7:642-645

16. Reidenberg JS, Laitman JT (2008) Sisters of the sinuses: cetacean air sacs. Anat Rec (Hoboken) 291:1389-1396

17. Berta A, Ekdale EG, Cranford TW (2014) Review of the cetacean nose: form function, and evolution. Anat Rec (Hoboken) 297:2205-2215

18. Negus V (1957) The function of the paranasal sinuses. AMA Arch Otolaryngol 66:430-442

19. Ignarro LJ, Byrns RE, Buga GM, Wood KS (1987) Endothelium-derived relaxing factor from pulmonary artery and vein possesses pharmacologic and chemical properties identical to those of nitric oxide radical. Circ Res 61:866-879

20. Palmer RM, Ferrige AG, Moncada S (1987) Nitric oxide release accounts for the biological activity of endothelium-derived relaxing factor. Nature 327: 524-526

21. Smith O (1998) Nobel Prize for NO research. Nat Med 4:1215

22. Gustafsson LE, Leone AM, Persson MG, Wiklund NP, Moncada S (1991) Endogenous nitric oxide is present in the exhaled air of rabbits, guinea pigs and humans. Biochem Biophys Res Commun 181:852-857

23. Lundberg JO, Weitzberg E, Nordvall SL, Kuylenstierna R, Lundberg JM, Alving K (1994) Primarily nasal origin of exhaled nitric oxide and absence in Kartagener's syndrome. Eur Respir J 7:1501-1504

24. Maniscalco M, Weitzberg E, Sundberg J, Sofia M, Lundberg JO (2003) Assessment of nasal and sinus nitric oxide output using single-breath humming exhalations. Eur Respir J 22:323-329

25. Maniscalco M, Sofia M, Weitzberg E, De Laurentiis G, Stanziola A, Rossillo V, Lundberg JO (2004) Humming-induced release of nasal nitric oxide for assessment of sinus obstruction in allergic rhinitis: pilot study. Eur J Clin Invest 34:555-560

26. Vaidyanathan S, Williamson P, Anderson K, Lipworth B (2010) Effect of systemic steroids on humming nasal nitric oxide in chronic rhinosinusitis with nasal polyposis. Ann Allergy Asthma Immunol 105:412-417

27. Bommarito L, Guida G, Heffler E, Badiu I, Nebiolo F, Usai A, De Stefani A, Rolla G (2008) Nasal nitric oxide concentration in suspected chronic rhinosinusitis. Ann Allergy Asthma Immunol 101:358-362
28. Liu C, Zheng M, He F, Wang X, Zhang L (2017) Role of exhaled nasal nitric oxide in distinguishing between chronic rhinosinusitis with and without nasal polyps. Am J Rhinol Allergy 31:389-394

29. Palmer RM, Ashton DS, Moncada S (1988) Vascular endothelial cells synthesize nitric oxide from L-arginine. Nature 333:664-666

30. Barnes PJ, Belvisi MG (1993) Nitric oxide and lung disease. Thorax 48:1034-1043

31. Shaul PW, North AJ, Wu LC, Wells LB, Brannon TS, Lau KS, Michel T, Margraf LR, Star RA (1994) Endothelial nitric oxide synthase is expressed in cultured human bronchiolar epithelium. J Clin Invest 94:2231-2236

32. Asano K, Chee CB, Gaston B, Lilly CM, Gerard C, Drazen JM, Stamler JS (1994) Constitutive and inducible nitric oxide synthase gene expression, regulation, and activity in human lung epithelial cells. Proc Natl Acad Sci USA 91:10089-10093

33. Haight JS, Djupesland PG, Qjan W, Chatkin JM, Furlott H, Irish J, Witterick I, McClean P, Fenton RS, Hoffstein V, Zamel N (1999) Does nasal nitric oxide come from the sinuses? J Otolaryngol 28:197-204

34. Serrano C, Valero A, Picado C (2004) Nasal nitric oxide. Arch Bronconeumol 40:222-230

35. Lundberg JO, Farkas-Szallasi T, Weitzberg E, Rinder J, Lidholm J, Anggaard A, Hokfelt T, Lundberg JM, Alving K (1995) High nitric oxide production in human paranasal sinuses. Nat Med 1:370-373

36. Muluk NB, Arikan OK, Atasoy P, Kilic R, Yalcinozan ET (2014) The role of endothelial nitric oxide synthase (eNOS) in the pathogenesis of sinonasal polyps. Eur Rev Med Pharmacol Sci 18:918-929

37. Muluk NB, Arikan OK, Atasoy P, Kilic R, Yalcinozan ET (2013) Inducible nitric oxide synthase (iNOS) in sinonasal polyp pathogenesis. B-ENT 9: 207-216

38. Ramis I, Lorente J, Rosello-Catafau J, Quesada P, Gelpi E, Bulbena O (1996) Differential activity of nitric oxide synthase in human nasal mucosa and polyps. Eur Respir J 9:202-206

39. Furukawa K, Harrison DG, Saleh D, Shennib H, Chagnon FP, Giaid A (1996) Expression of nitric oxide synthase in the human nasal mucosa. Am J Respir Crit Care Med 153:847-850

40. Gungor AA, Martino BJ, Dupont SC, Kuo L (2013) A human study model for nitric oxide research in sinonasal disease. Am J Otolaryngol 34:337-344

41. Holden WE, Sippel JM, Nelson B, Giraud GD (2009) Greater nasal nitric oxide output during inhalation: effects on air temperature and water content. Respir Physiol Neurobiol 165:22-27

42. Frostell C, Fratacci MD, Wain JC, Jones R, Zapol WM (1991) Inhaled nitric oxide. A selective pulmonary vasodilator reversing hypoxic pulmonary vasoconstriction. Circulation 83:2038-2047

43. Frostell CG, Blomqvist H, Hedenstierna G, Lundberg J, Zapol WM (1993) Inhaled nitric oxide selectively reverses human hypoxic pulmonary vasoconstriction without causing systemic vasodilation. Anesthesiology 78: $427-435$

44. DeMarco V, Skimming JW, Ellis TM, Cassin S (1996) Nitric oxide inhalation effects on the ovine neonatal pulmonary and systemic circulations. Reprod Fertil Dev 8:431-438

45. Roberts JD Jr, Chen TY, Kawai N, Wain J, Dupuy P, Shimouchi A, Bloch K, Polaner D, Zapol WM (1993) Inhaled nitric oxide reverses pulmonary vasoconstriction in the hypoxic and acidotic newborn lamb. Circ Res 72 : 246-254

46. Roberts JD Jr, Lang P, Bigatello LM, Vlahakes GJ, Zapol WM (1993) Inhaled nitric oxide in congenital heart disease. Circulation 87:447-453

47. Turanlahti MI, Laitinen PO, Sarna SJ, Pesonen E (1998) Nitric oxide, oxygen, and prostacyclin in children with pulmonary hypertension. Heart 79:169-174

48. Approval Letter by US Food and Drug Administration on the FDA website. https://www.accessdata.fda.gov/drugsatfda_docs/nda/99/20845_INOmax_ Approv.pdf. Accessed 19 Nov 2018.

49. Hunt JL, Bronicki RA, Anas N (2016) Role of inhaled nitric oxide in the management of severe acute respiratory distress syndrome. Front Pediatr 4:74

50. Goodman RS, Goodman M, Gootman N, Cohen H (1976) Cardiac and pulmonary failure secondary to adenotonsillar hypertrophy. Laryngoscope 86:1367-1374

51. Sie KC, Perkins JA, Clarke WR (1997) Acute right heart failure due to adenotonsillar hypertrophy. Int J Pediatr Otorhinolaryngol 41:53-58

52. Kumar EB, Jaggarao NS (1989) Adenotonsillar hypertrophy and cor pulmonale: clinical and echocardiographic correlation. Postgrad Med J 65: $473-475$

53. Acar OC, Uner A, Garca MF, Ece I, Epcacan S, Turan M, Kalkan F (2016) The effect of tonsillectomy and adenoidectomy on right ventricle function and 
pulmonary artery pressure by using doppler echocardiography in children Clin Exp Otorhinolaryngol 9:163-167

54. Ramakrishna S, Ingle VS, Patel S, Bhat P, Dada JE, Shah FA, Murty PS (2000) Reversible cardio-pulmonary changes due to adeno-tonsilar hypertrophy. Int J Pediatr Otorhinolaryngol 55:203-206

55. Marangu D, Jowi C, Aswani J, Wambani S, Nduati R (2014) Prevalence and associated factors of pulmonary hypertension in Kenyan children with adenoid or adenotonsillar hypertrophy. Int J Pediatr Otorhinolaryngol 78: $1381-1386$

56. Koc S, Aytekin M, Kalay N, Ozcetin M, Burucu T, Ozbek K, Celik A, Kadi H, Gulturk S, Koc F (2012) The effect of adenotonsillectomy on right ventricle function and pulmonary artery pressure in children with adenotonsillar hypertrophy. Int J Pediatr Otorhinolaryngol 76:45-48

\section{Publisher's Note}

Springer Nature remains neutral with regard to jurisdictional claims in published maps and institutional affiliations.

\section{Submit your manuscript to a SpringerOpen ${ }^{\circ}$ journal and benefit from:}

- Convenient online submission

- Rigorous peer review

- Open access: articles freely available online

High visibility within the field

- Retaining the copyright to your article

Submit your next manuscript at $\boldsymbol{\nabla}$ springeropen.com 